\title{
lodine-catalyzed electrophilic substitution of indoles: Synthesis of (un)symmetrical diindolylmethanes with a quaternary carbon center
}

\author{
Thanigaimalai Pillaiyar ${ }^{*} 1,2$, Masoud Sedaghati ${ }^{1}$, Andhika B. Mahardhika ${ }^{1,3}$, \\ Lukas L. Wendt ${ }^{1}$ and Christa E. Müller ${ }^{*} 1,3$
}

\section{Full Research Paper}

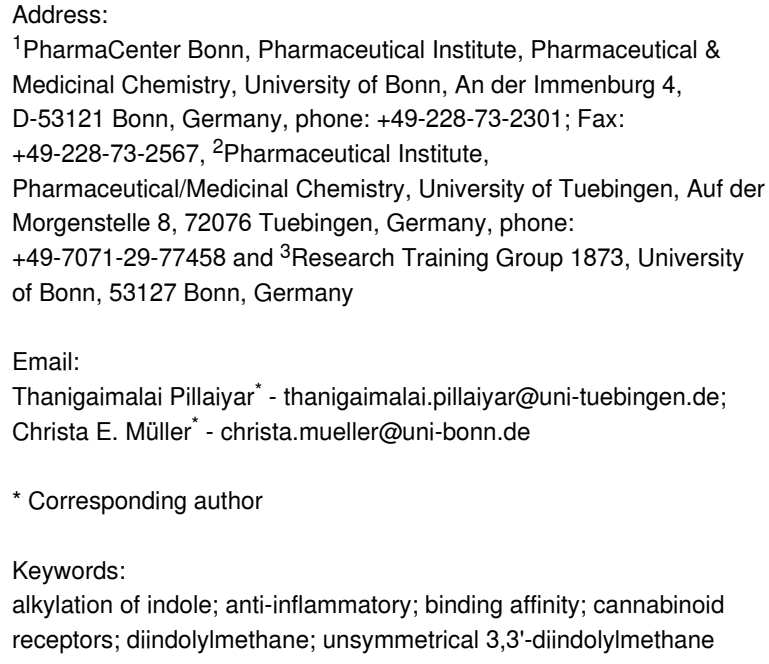

${ }^{1}$ PharmaCenter Bonn, Pharmaceutical Institute, Pharmaceutical \& Medicinal Chemistry, University of Bonn, An der Immenburg 4, D-53121 Bonn, Germany, phone: +49-228-73-2301; Fax: +49-228-73-2567, 2Pharmaceutical Institute,

Pharmaceutical/Medicinal Chemistry, University of Tuebingen, Auf der Morgenstelle 8, 72076 Tuebingen, Germany, phone: +49-7071-29-77458 and ${ }^{3}$ Research Training Group 1873, University of Bonn, 53127 Bonn, Germany

Email:

Thanigaimalai Pillaiyar ${ }^{\star}$ - thanigaimalai.pillaiyar@uni-tuebingen.de; Christa E. Müller* - christa.mueller@uni-bonn.de

* Corresponding author

Keywords:

alkylation of indole; anti-inflammatory; binding affinity; cannabinoid receptors; diindolylmethane; unsymmetrical 3,3'-diindolylmethane

\author{
Beilstein J. Org. Chem. 2021, 17, 1464-1475. \\ https://doi.org/10.3762/bjoc.17.102 \\ Received: 31 March 2021 \\ Accepted: 08 June 2021 \\ Published: 18 June 2021 \\ Associate Editor: T. J. J. Müller \\ (c) 2021 Pillaiyar et al.; licensee Beilstein-Institut. \\ License and terms: see end of document.
}

\begin{abstract}
A novel, versatile approach for the synthesis of unsymmetrical 3,3'-diindolylmethanes (DIMs) with a quaternary carbon center has been developed via iodine-catalyzed coupling of trifluoromethyl(indolyl)phenylmethanols with indoles. In contrast to previously reported methods, the new procedure is characterized by chemoselectivity, mild conditions, high yields, and scalability to obtain gram amounts for biological studies. Selected compounds were found to display affinity for cannabinoid receptors, which are promising drug targets for the treatment of inflammatory and neurodegenerative diseases.
\end{abstract}

\section{Introduction}

Diindolylmethanes (DIMs) represent an important class of indole alkaloids, that are constituents of pharmaceuticals [1-7] and agrochemicals [8,9]. DIM derivatives possess a variety of biological activities (Figure 1) [10]. Unsubstituted DIM (I), for example, exhibits antimicrobial [5], anticancer [11-13], and anti-inflammatory effects (Figure 1) [14]. There is preclinical evidence for activity against several types of cancer [15], and DIM has been clinically evaluated for the treatment of prostate 
cancer [16] and showed promise for the treatment of cervical dysplasia [17]. The related trisindoline (II) was reported to possess antibiotic activity [18], while DIM derivatives III and IV also showed anticancer activities (Figure 1). Owing to their exciting biological activities, DIM derivatives have recently received increasing attention from synthetic organic chemists, biologists, and pharmacologists.

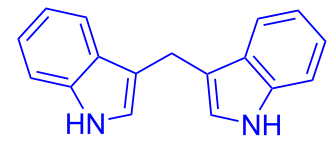

3,3'-diindolylmethane (I) antimicrobial, anticancer, antioxidant, anti-inflammatory

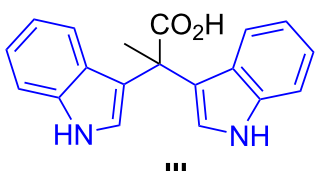

III anticancer activity

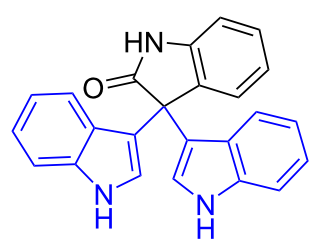

trisindoline (II) antidiabetic, antibiotic

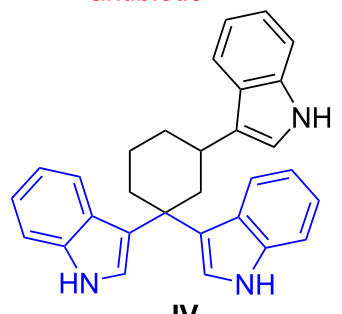

IV
Figure 1: Diindolylmethanes and reported biological activities.

In general, DIMs can be synthesized via electrophilic substitution of indoles by aldehydes or ketones in the presence of conventional Lewis or Brønsted acids as catalysts [19]. This strategy is straightforward, but it always only provides symmetrical DIMs. The synthesis of unsymmetrical DIM derivatives, however, remains challenging, and merely sporadic examples are reported in literature [20,21].

Methods for the introduction of fluorinated groups into organic molecules are of high interest due to fluorine's unique physical and chemical properties, such as its small size, high electronegativity, and high C-F bond dissociation energy [22-24]. Organofluoro compounds developed as drug molecules often display increased metabolic stability and bioavailability compared to non-fluorinated analogs [25]. Considering the evergrowing demand for organofluorine compounds, the development of new methodologies that allow the incorporation of fluorine atoms into bioactive molecules is highly desired and will also be addressed herein.

Recently, the use of indol-3-ylmethanols as electrophiles has emerged as a powerful strategy for constructing synthetically valuable indol-3-yl-containing molecules. In particular, the reaction of indol-3-ylmethanols with indoles has become a useful route for the preparation of tertiary unsymmetrical 3,3'DIMs [26-35]. However, synthetic methods for efficient synthesis of unsymmetrical 3,3'-DIMs with a quaternary carbon center, including trifluoromethyl-substituted 3,3'-DIMs, are still rare.

Sasaki et al. reported the reaction of trifluoromethyl(indolyl)phenylmethanols with indoles in the presence of trifluoroacetic acid (TFA) and $\mathrm{CHCl}_{3}$ (Figure 2) [36]. Very recently, Ling et al. reported the same reaction in the presence of $\mathrm{Ga}(\mathrm{OTf})_{3}$ in acetonitrile (Figure 2) [37]. Although these methods are certainly useful, they have several undeniable drawbacks, including the use of heavy-metal catalysts and the necessity of employing indoles bearing bulky substituents at their 2-position (Ling et al.), or the need for chlorinated solvents (Sasaki et al.), as well as difficulty to scale up the reactions to a multigram scale, as well as a generally rather limited substrate scope. Therefore, finding a robust method with a broad substrate scope and functional group tolerance is highly desirable.

As part of our continuous efforts to prepare biologically active DIM derivatives [38], we herein report an innovative approach to synthesize unsymmetrical 3,3'-diindolylmethanes (DIMs) with a fluoromethyl-containing quaternary carbon center via an iodine-catalyzed coupling reaction of trifluoromethyl(indolyl)phenylmethanol with indole derivatives. This method has also been extended to the synthesis of pentafluoro-ethylated and heptafluoro-propylated DIMs in excellent yields. Selected compounds were evaluated in radioligand binding studies for their affinities towards cannabinoid $\mathrm{CB}_{1}$ and $\mathrm{CB}_{2}$ receptors.

\section{Results and Discussion Optimization of the reaction}

The reaction conditions were optimized using 2,2,2-trifluoro-1(5-methoxy-1H-indol-3-yl)-1-phenylethan-1-ol (1a, 5 mmol) and $1 H$-indole (2a, $5 \mathrm{mmol}$ ) as model substrates (Table 1$)$. At first, the reaction was attempted in trifluoroethanol (TFE), and water, respectively, as these solvents had been utilized for the preparation of unsymmetrical DIMs from $(1 H$-indol-3-yl)(phenyl)methanol by Xiao and co-workers [39,40]. However, no product was formed in either solvent even at high temperatures (Table 1, entries 1-3). This is likely due to the steric hindrance of the $\mathrm{CF}_{3}$-substituted quaternary carbon atom in substrate $\mathbf{1 a}$. Therefore, the solvent was changed to $\mathrm{H}_{2} \mathrm{SO}_{4}(5 \%)$ in water (Table 1, entry 4) or glacial acetic acid (entry 5), and the reactions were performed at room temperature. While no reaction occurred in $5 \% \mathrm{H}_{2} \mathrm{SO}_{4}$, traces of product were observed in acetic acid (entry 5). Therefore, the reaction mixture was gradually heated to $50{ }^{\circ} \mathrm{C}$ (Table 1 , entry 6), $80{ }^{\circ} \mathrm{C}$ (entry 7), and 
Sasaki, S. et al. (2012) [36]

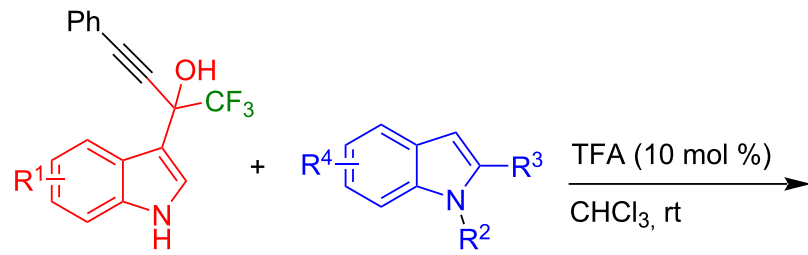<smiles>[R1]c1ccc2[nH]cc(C(C#Cc3ccccc3)(c3c([R])n([R])c4ccc([R1])cc34)C(F)(F)F)c2c1</smiles>

$79-98 \%$

Ling, Y. et al. (2019) [37]

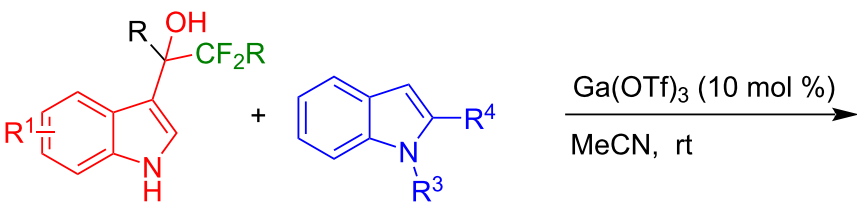<smiles>[R16]c1ccc2[nH]cc(C([R])(F)c3c([R])n([R3])c4cccc([R])c34)c2c1</smiles>

This work<smiles>[R]C([R])C(O)([Al])c1c[nH]c2cc[R1]cc12</smiles>

$\mathrm{R}^{1}=\mathrm{EDG}, \mathrm{EWG}, \mathrm{H}$ $\mathrm{R}^{2}=\mathrm{F}, \mathrm{CF}_{3}, \mathrm{C}_{2} \mathrm{~F}_{5}$

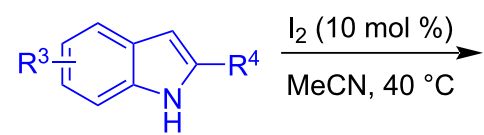

$\mathrm{R}^{3}=\mathrm{EDG}, \mathrm{EWG}, \mathrm{H}$ $\mathrm{R}^{4}=\mathrm{H}, \mathrm{CH}_{3}$

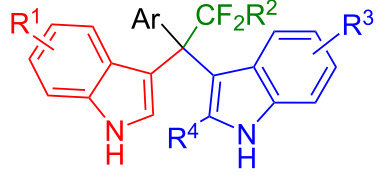

$61-99 \%$

Figure 2: Synthetic strategies toward trifluoromethylated unsymmetrical quaternary DIMs.

$100{ }^{\circ} \mathrm{C}$ (entry 8). To our delight, the formation of the expected product was steadily increased to 32,47 , and $56 \%$, respectively. Nevertheless, it was not possible to further increase the yield of the product using this solvent.
For subsequent attempts, we investigated the reaction using different Lewis acid catalysts, including $\mathrm{AlCl}_{3}$ (Table 1, entry 9, $10 \%$ yield), $\mathrm{FeCl}_{3}$ (entry 10, 17\%), $\mathrm{I}_{2}$ (entry $11,51 \%$ ), $p$ - $\mathrm{TsOH}$ (entry $12,5 \%$ ), and $\mathrm{InCl}_{3}$ (entry 13 , traces), in acetonitrile at

Table 1: Optimization of the reaction conditions for the preparation of 5-methoxy-3-(2,2,2-trifluoro-1-(1H-indol-3-yl)-1-phenylethyl)-1H-indole $(3 \mathrm{a})^{\mathrm{a}}$.<smiles>COc1ccc2[nH]cc(C(O)(c3ccccc3)C(F)(F)F)c2c1</smiles>

$1 \mathrm{a}$<smiles>c1ccc2[nH]ccc2c1</smiles>

conditions

$2 a$<smiles>COc1ccc2[nH]cc(C(c3ccccc3)(c3ccccc3)c3c[nH]c4ccccc34)c2c1</smiles>

$3 a$

\begin{tabular}{|c|c|c|c|c|c|}
\hline Entry & Solvent & Catalyst & Temp. $\left({ }^{\circ} \mathrm{C}\right)$ & Time (h) & Yield $(\%)^{b}$ \\
\hline 1 & trifluoroethanol & - & $\mathrm{rt}$ & 24 & $0^{c}$ \\
\hline 2 & trifluoroethanol & - & 80 & 24 & $0^{c}$ \\
\hline 3 & $\mathrm{H}_{2} \mathrm{O}$ & - & 100 & 24 & $0^{c}$ \\
\hline 4 & $5 \% \mathrm{H}_{2} \mathrm{SO}_{4}$ in $\mathrm{H}_{2} \mathrm{O}$ & - & $\mathrm{rt}$ & 24 & $0^{c}$ \\
\hline 5 & $\mathrm{CH}_{3} \mathrm{COOH}$ & - & $\mathrm{rt}$ & 24 & traces \\
\hline 6 & $\mathrm{CH}_{3} \mathrm{COOH}$ & - & 50 & 24 & 32 \\
\hline 7 & $\mathrm{CH}_{3} \mathrm{COOH}$ & - & 80 & 24 & 47 \\
\hline
\end{tabular}




\begin{tabular}{|c|c|c|c|c|c|}
\hline 8 & $\mathrm{CH}_{3} \mathrm{COOH}$ & - & 100 & 24 & 56 \\
\hline 9 & $\mathrm{MeCN}$ & $\begin{array}{l}\mathrm{AlCl}_{3} \\
(10 \mathrm{~mol} \%)\end{array}$ & rt & 24 & 10 \\
\hline 10 & $\mathrm{MeCN}$ & $\begin{array}{l}\mathrm{FeCl}_{3} \\
(10 \mathrm{~mol} \%)\end{array}$ & rt & 24 & 17 \\
\hline 11 & $\mathrm{MeCN}$ & $\mathrm{I}_{2}(10 \mathrm{~mol} \%)$ & rt & 24 & 51 \\
\hline 12 & $\mathrm{MeCN}$ & $\begin{array}{l}p \text {-TsOH } \\
(10 \mathrm{~mol} \%)\end{array}$ & rt & 24 & 5 \\
\hline 13 & $\mathrm{MeCN}$ & $\begin{array}{l}\mathrm{InCl}_{3} \\
(10 \mathrm{~mol} \%)\end{array}$ & rt & 12 & traces \\
\hline 14 & $\mathrm{MeCN}$ & $\begin{array}{l}\mathrm{FeCl}_{3} \\
(10 \mathrm{~mol} \%)\end{array}$ & 40 & 12 & 67 \\
\hline 15 & $\mathrm{MeCN}$ & $\begin{array}{l}p \text {-TsOH } \\
(10 \mathrm{~mol} \%)\end{array}$ & 40 & 24 & 15 \\
\hline 16 & $\mathrm{MeCN}$ & $\mathrm{I}_{2}(10 \mathrm{~mol} \%)$ & 40 & 5 & 98 \\
\hline 17 & $\mathrm{MeCN}$ & $\mathrm{I}_{2}(10 \mathrm{~mol} \%)$ & 80 & 5 & 95 \\
\hline 18 & $\mathrm{MeCN}$ & $\mathrm{I}_{2}(5 \mathrm{~mol} \%)$ & 40 & 12 & 89 \\
\hline
\end{tabular}

aReactions of $1 \mathbf{a}(5 \mathrm{mmol})$ and $\mathbf{2 a}(5 \mathrm{mmol})$ were performed in $5 \mathrm{~mL}$ of solvent. ${ }^{\mathrm{b}}$ Isolated yields after column chromatography. ${ }^{\mathrm{C}} \mathrm{No}$ reaction. MeCN, acetonitrile. rt, room temperature.

room temperature. Among these, the presence of $\mathrm{I}_{2}$ led to the highest yield of $51 \%$ (Table 1 , entry 11 ). This trend was consistent: Upon heating to $40{ }^{\circ} \mathrm{C}$, reactions with $\mathrm{FeCl}_{3}$ (Table 1 , entry 14 ) or $p$ - $\mathrm{TsOH}$ (entry 15 ) yielded $67 \%$ and $15 \%$ of product, respectively, while $98 \%$ of the product was obtained in the presence of $\mathrm{I}_{2}$ (Table 1, entry 16). However, further increase of the reaction temperature to $80{ }^{\circ} \mathrm{C}$ did not significantly affect the generation of the product (Table 1, entry 17). Lowering the amount of catalyst from $10 \mathrm{~mol} \%$ to $5 \mathrm{~mol} \%$ reduced the product formation (Table 1, entry 18).

Having optimized the reaction conditions $\left(\mathrm{I}_{2}, 10 \mathrm{~mol} \%, 40{ }^{\circ} \mathrm{C}\right.$ for $5 \mathrm{~h}$ in $\mathrm{MeCN}$; entry 16, Table 1), we explored the scope of the reaction. At first, we employed differently substituted indole derivatives (Table 2). A large variety of substituted indoles was well tolerated, and their reactions with 1a provided the desired products in good to excellent yields (61-99\%). Reaction of $1 \mathbf{a}$ with indoles bearing electron-donating substituents, such as methoxy (2b) or hydroxy (2f), afforded the products in good yields (3b: 67\%; 3f: 61\%). Coupling of 1a with indoles substituted with electron-withdrawing groups, including cyano (2c), fluoro (2d, 2e, 2h), and bromo (2g), likewise resulted in good to excellent yields of the desired products (3c: 65\%, 3d: 99\%, 3e: 96\%, 3g: 95\%, 3h: 91\%).

Shifting the position of the methoxy group of $\mathbf{1 a}$ from position 5 to $4(\mathbf{1 b})$ or 6 (1c) also led to the formation of the products in very good yields $(\mathbf{3 i}: 77 \%, \mathbf{3 j}: 89 \%, \mathbf{3 k}$ :

Table 2: Substrate scope of the reaction with differently substitute indole derivatives 2.<smiles>OC(c1ccccc1)(c1c[nH]c2cc[R1]cc12)C(F)(F)F</smiles>

1a: $\mathrm{R}^{1}=5-\mathrm{OCH}_{3}$

1b: $\mathrm{R}^{1}=4-\mathrm{OCH}_{3}$

1c: $\mathrm{R}^{1}=6-\mathrm{OCH}_{3}$

1d: $R^{1}=6-F$

1e: $R^{1}=H$<smiles>[R]c1cc2cc[R]cc2[nH]1</smiles>

$\underset{5 \mathrm{~h}, \mathrm{MeCN}}{\stackrel{\mathrm{I}_{2}(10 \mathrm{~mol} \%), 40^{\circ} \mathrm{C}}{\longrightarrow}}$

2e: $R^{2}=H, R^{3}=6-F$

2a: $R^{2}, R^{3}=H$

2b: $R^{2}=H, R^{3}=4-O_{3}$

2c: $R^{2}=H, R^{3}=4-C N$

2d: $R^{2}=H, R^{3}=5-F$

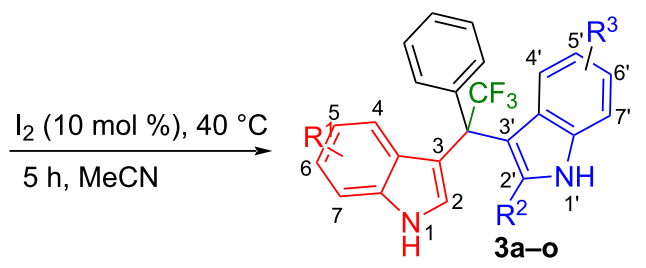

2f: $R^{2}=H, R^{3}=6-O H$

2g: $R^{2}=H, R^{3}=7-B r$

2h: $R^{2}=H, R^{3}=5,6-d i F$

2i: $\mathrm{R}^{2}=\mathrm{CH}_{3}, \mathrm{R}^{3}=\mathrm{H}$ 
Table 2: Substrate scope of the reaction with differently substitute indole derivatives 2. (continued)

Yields of products $\mathbf{3 a - 0}$

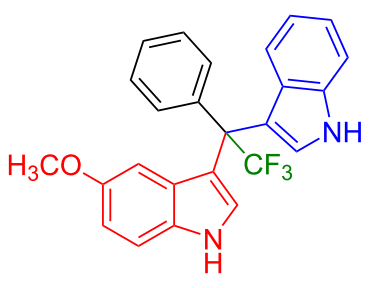

3a $(98 \%)(81 \%)[35]$

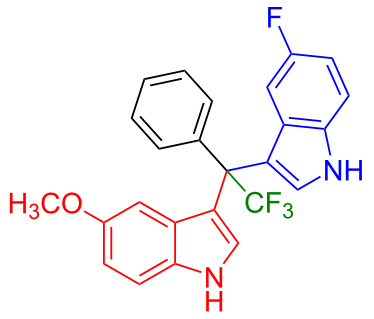

3d (99\%), (80\%)[35]<smiles>COc1ccc2[nH]cc(C(F)(F)c3c[nH]c4c(Br)cccc34)c2c1</smiles>

$3 g(95 \%)$

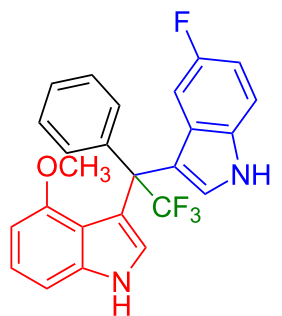

3j (89\%)

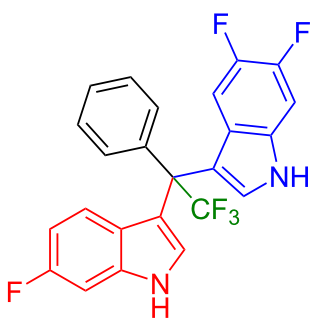

$3 m(89 \%)$<smiles>COc1ccc2[nH]cc(C(F)(F)c3c[nH]c4cccc(OC)c34)c2c1</smiles>

3b $(67 \%)$<smiles>COc1ccc2[nH]cc(C(F)(F)C(c3ccccc3)c3c[nH]c4cc(F)ccc34)c2c1</smiles>

3e $(96 \%)$<smiles>COc1ccc2[nH]cc(C(F)(c3ccccc3)c3c[nH]c4cc(F)c(F)cc34)c2c1</smiles>

3h $(91 \%)$<smiles>COc1ccc2c(C(F)(c3ccccc3)c3c[nH]c4ccccc34)c[nH]c2c1</smiles>

3k $(70 \%)$

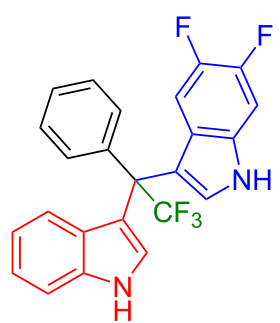

3n (99\%)<smiles>COc1ccc2[nH]cc(C(F)(c3ccccn3)c3c[nH]c4cccc(C#N)c34)c2c1</smiles>

$3 c(65 \%)$<smiles>COc1ccc2[nH]cc(C(F)(F)C(c3ccccc3)c3c[nH]c4cc(O)ccc34)c2c1</smiles>

$3 \mathbf{f}(61 \%)$

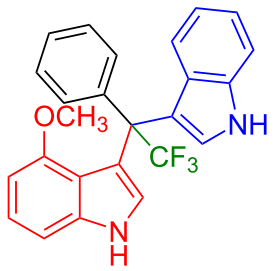

$3 \mathbf{i}(77 \%)$<smiles>COc1ccc2c(C(F)(c3ccccc3)c3c[nH]c4c(Br)cccc34)c[nH]c2c1</smiles>

$3 \mathbf{l}(72 \%)$

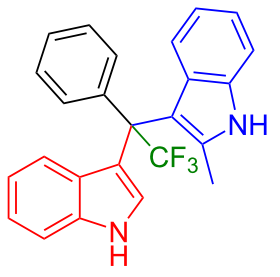

$30(87 \%)$
70\%, 31: 72\%). The intermediates 1d with 6-fluoro or $1 \mathbf{e}$ without substituent on the indole ring reacted with 5,6-difluoroindole (2h) and formed the desired products in excellent yields of $89 \%$ (3m) and $99 \%$ (3n). Besides, 2-methylindole (2i) smoothly reacted with $\mathbf{1 e}$, affording product 30 in $87 \%$ yield.
Next, we studied the substrate scope of the trifluoromethyl(indolyl)phenylmethanols 1 with respect to the substitution of the phenyl ring (Table 3). The derivatives bearing $p$-tolyl (1f), $p$-fluorophenyl (1g), or $p$-bromophenyl (1g) rings reacted with a series of halogenated indoles (2d, $2 \mathbf{e}, \mathbf{2 f}, \mathbf{2 g}, \mathbf{2 h}$, and $\mathbf{2 j}$ ) providing the unsymmetrical DIMs (3p: $99 \%$, 3q: $98 \%$, 3r: $87 \%$, 3s: 
Table 3: Substrate scope of the reaction of 1f-i with trifluoromethyl(indolyl)phenylmethanols 1: modification of the aryl group.

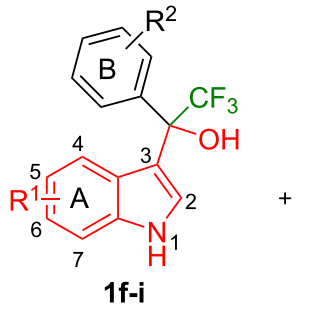

1f: $\mathrm{R}^{1}=5-\mathrm{OCH}_{3}, \mathrm{R}^{2}=p-\mathrm{CH}_{3}$

1g: $\mathrm{R}^{1}=5-\mathrm{OCH}_{3}, \mathrm{R}^{2}=p-\mathrm{F}$

1h: $\mathrm{R}^{1}=5-\mathrm{OCH}_{3}, \mathrm{R}^{2}=p-\mathrm{Br}$

ii: $\mathrm{R}^{1}=5-\mathrm{OCH}_{3}$, ring $\mathrm{B}=-\xi-$

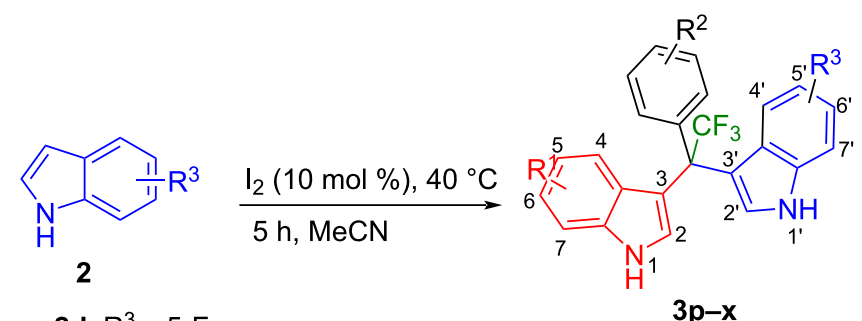

2d: $R^{3}=5-F$

2e: $R^{3}=6-F$

2h: $\mathrm{R}^{3}=5,6-\mathrm{diF}$

2g: $R^{3}=7-B r$

2j: $R^{3}=6-B r$

Yields of products $3 p-\mathbf{x}$<smiles>COc1ccc2[nH]cc(C(c3ccc(C)cc3)(c3ccc(F)cc3)C(F)(F)F)c2c1</smiles>

3p (99\%)<smiles>COc1ccc2[nH]cc(C(F)(c3ccc(Br)cc3)C(F)(F)c3c[nH]c4cc(Br)ccc34)c2c1</smiles>

3s $(90 \%)$<smiles>COc1ccc2[nH]cc(C(F)(c3cccs3)C(F)(F)c3c[nH]c4ccccc34)c2c1</smiles>

3v $(89 \%)$<smiles></smiles>

$3 q(98 \%)$<smiles>COc1ccc2[nH]cc(C(F)(c3ccc(Br)cc3)C(F)(F)c3c[nH]c4c(Br)cccc34)c2c1</smiles>

3t $(82 \%)$<smiles>COc1ccc2[nH]cc(C(F)(c3cccs3)c3c[nH]c4ccc(F)cc34)c2c1</smiles>

3w $(90 \%)$<smiles>COc1ccc2[nH]cc(C(F)(c3ccc(F)cc3)C(F)(F)c3c[nH]c4cc(F)c(F)cc34)c2c1</smiles>

$3 r(87 \%)$<smiles>COc1ccc2[nH]cc(C(c3ccc(Br)cc3)(c3c[nH]c4cc(F)c(F)cc34)C(F)(F)F)c2c1</smiles>

3u $(92 \%)$<smiles>COc1ccc2[nH]cc(C(F)(c3cccs3)C(F)(F)c3c[nH]c4cc(F)c(F)cc34)c2c1</smiles>

$3 x(82 \%)$
$90 \%, 3 t: 82 \%, 3 u: 92 \%)$ in excellent yields ranging from $82-99 \%$. It was interesting to see that a compound, in which the phenyl ring of $\mathbf{1}$ was replaced by the heteroaryl moiety thiophene (1i), reacted efficiently with a series of indole derivatives $(\mathbf{2 a}, \mathbf{2 d}, \mathbf{2 h})$ providing yields of $82-90 \%(\mathbf{3} \mathbf{v}-\mathbf{x})$.
We further extended this protocol to the preparation of unsymmetrical pentafluoroethylated and heptafluoropropylated DIM derivatives (Table 4). The (indol-3-yl)phenylmethanol derivative bearing a pentafluoroethyl residue $(\mathbf{1 j})$ was efficiently reacted with a series of indole derivatives $(\mathbf{2 d}, \mathbf{2 e}, \mathbf{2 h}, \mathbf{2} \mathbf{j}$, and 
Table 4: Substrate scope of the reaction of $\mathbf{1 j} \mathbf{j}-\mathbf{I}$ with trifluoromethyl(indolyl)phenylmethanols 1: modification of the trifluoromethyl group.

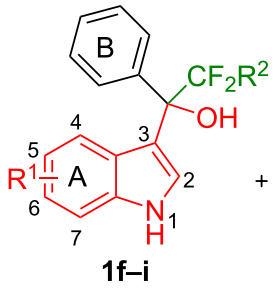

$1 \mathrm{j}: \mathrm{R}^{1}=5-\mathrm{OCH}_{3}, \mathrm{R}^{2}=\mathrm{CF}_{3}$ 1k: $\mathrm{R}^{1}=5-\mathrm{OCH}_{3}, \mathrm{R}^{2}=\mathrm{CF}_{2} \mathrm{CF}_{3}$<smiles></smiles>

$\underset{5 \mathrm{~h}, \mathrm{MeCN}}{\stackrel{\mathrm{I}_{2}(10 \mathrm{~mol} \%), 40{ }^{\circ} \mathrm{C}}{\longrightarrow}}$

2a: $\mathrm{R}^{3}=\mathrm{H}$

2d: $R^{3}=5-F$

$2 e: R^{3}=6-F$ 2h: $R^{3}=5,6-d i F$

2j: $\mathrm{R}^{3}=6-\mathrm{Br}$

2k: $R^{3}=4,5-\mathrm{diF}$

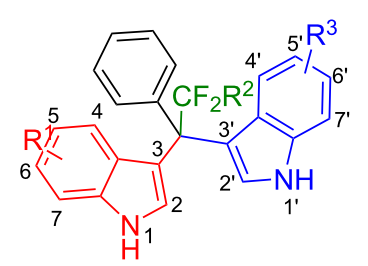

3y, 3z, 3aa-ag

Yields of products $\mathbf{3 y}, \mathbf{z}, \mathbf{a a}-\mathbf{a g}$<smiles>COc1ccc2[nH]cc(C(F)(F)C(c3ccccc3)c3c[nH]c4ccc(F)cc34)c2c1</smiles>

3y $(96 \%)$<smiles></smiles>

3ab (86\%)<smiles></smiles><smiles>COc1ccc2c(C(c3ccccc3)(c3c[nH]c4cc(Br)ccc34)C(F)(F)F)c[nH]c2c1</smiles>

$3 \mathbf{z}(89 \%)$<smiles></smiles>

3ac (92\%)

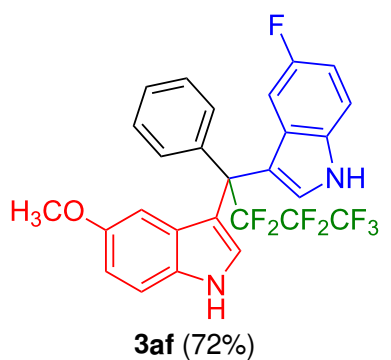<smiles>COc1ccc2[nH]cc(C(F)(F)C(c3ccccc3)(c3ccccc3)c3c[nH]c4cc(F)ccc34)c2c1</smiles>

3aa $(90 \%)$<smiles>COc1ccc2[nH]cc(C(F)(F)C(F)(F)F)c2c1C(c1ccccc1)c1c[nH]c2ccccc12</smiles>

$\operatorname{3ad}(94 \%)$

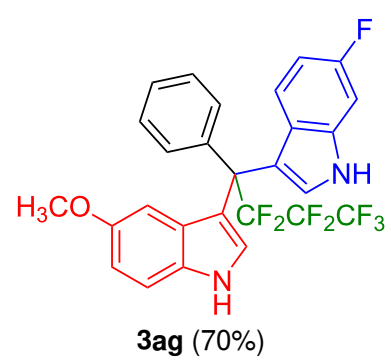

2k) substituted either both electron-donating or electron-withdrawing groups, and provided the desired products (3y: $96 \%$, 3z: $89 \%$, 3aa: $90 \%$, 3ab: $86 \%$, 3ac: $92 \%$, 3ad: $94 \%$ ) in excellent yields (86-96\%).

The (indol-3-yl)phenylmethanol derivative bearing a heptafluoropropyl residue (1k) underwent coupling reactions with indole derivatives (2a, 2d, and $\mathbf{2 e}$ ) and yielded the expected products (3ae: $65 \%$, 3af: $72 \%$, 3ag: $70 \%$ ) in very good yields $(65-72 \%$ ). It was observed that the yield of heptafluoropropylated DIMs was slightly lower compared to their pentafluoroethylated congeners (compare 3y: $96 \%$ vs 3af: 72\%, and 3aa: $90 \%$ vs 3ag $70 \%)$.

Next, the necessity of the fluoroalkyl substituent was investigated to study the scope of the reaction. The non-fluorinated (indol-3-yl)phenylmethanol derivative bearing a methyl residue (11) and $2 \mathbf{c}$ or $\mathbf{2 d}$ were reacted applying the optimized conditions. However, the desired products 3ah and 3ai were not produced (Figure 3). These experiments indicated that the presence of a fluoroalkyl substituent was indeed essential for the alkylation of indoles. 


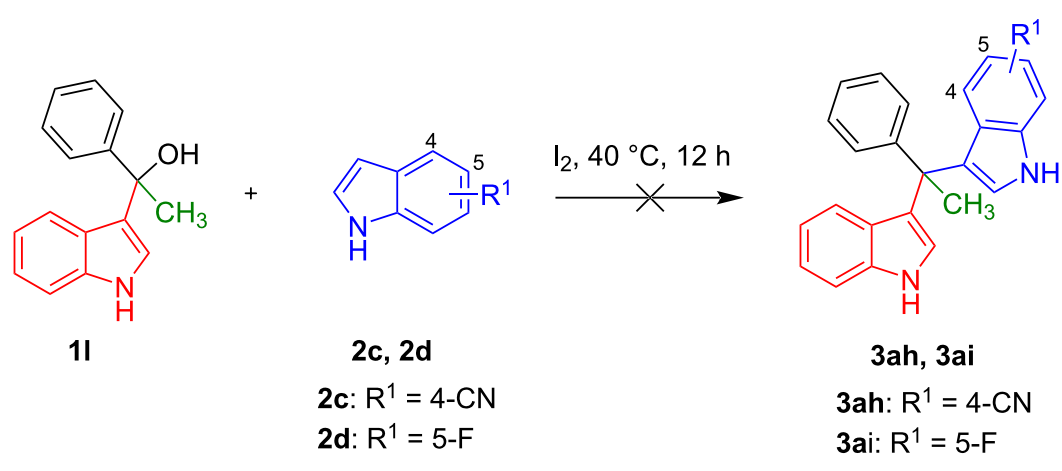

Figure 3: Reactions performed to study the scope of the method.

We further investigated the new method's feasibility for largescale synthesis (Figure 4). Thus, 2,2,2-trifluoro-1-(5-methoxy$1 H$-indol-3-yl)-1-phenylethan-1-ol (1a, $1.0 \mathrm{~g}, 3.10 \mathrm{mmol})$ and 2,2,3,3,3-pentafluoro-1-(5-methoxy-1H-indol-3-yl)-1-phenylpropan-1-ol (1j, $1.0 \mathrm{~g}, 2.7 \mathrm{mmol})$ were reacted with indole (2a, $0.40 \mathrm{~g}, 3.4 \mathrm{mmol}$; and $0.347 \mathrm{~g}, 2.9 \mathrm{mmol}$, respectively). The reactions proceeded without significant loss in efficiency, affording $1.2 \mathrm{~g}$ of $\mathbf{3 a}$ (92\% yield) and $1.10 \mathrm{~g}$ of $\mathbf{3 a d}(87 \%$ yield).

The unsubstituted diindolylmethane (I, Figure 1) was previously reported to bind to the cannabinoid receptors, $\mathrm{CB}_{1}\left(K_{\mathrm{i}} 4.3\right.$ $\mu \mathrm{M})$ and $\mathrm{CB}_{2}\left(K_{\mathrm{i}} 1.1 \mu \mathrm{M}\right)$ [41]. Both receptors are considered important therapeutic targets, e.g. for neurodegenerative and inflammatory diseases. Selected final products $(\mathbf{3 a}, \mathbf{3 b}, \mathbf{3 e}, \mathbf{3 g}, \mathbf{3 h}$, 3n, 3ad) were tested for their binding affinities towards human $\mathrm{CB}_{1}$ and $\mathrm{CB}_{2}$ receptors (Table 5).

At the $\mathrm{CB}_{1}$ receptor, compound $\mathbf{3 a}$ with a methoxy substituent on one of the two indole rings showed equipotent affinity to lead compound I, while introducing an additional 4-methoxy moiety into the second indole ring reduced binding affinity (3b). Compounds bearing 5-OMe,6'-F (3e), 5-OMe,7'-Br (3g), and 5-OMe,5',6'-diF substitution (3h) exhibited similar binding affinities to lead compound I. 5,6-DiF-DIM derivative $3 \mathbf{n}\left(\mathrm{CB}_{1}\right.$ : $K_{\mathrm{i}} 2.04 \mu \mathrm{M}$ ) showed a slightly improved binding affinity compared to lead compound I. These results suggest that compounds with small substituents like fluoro on only one indole ring are favorable for $\mathrm{CB}$ receptor binding. The pentafluoroethylated DIM derivative 3ad was the best $\mathrm{CB}_{1}$ ligand of the

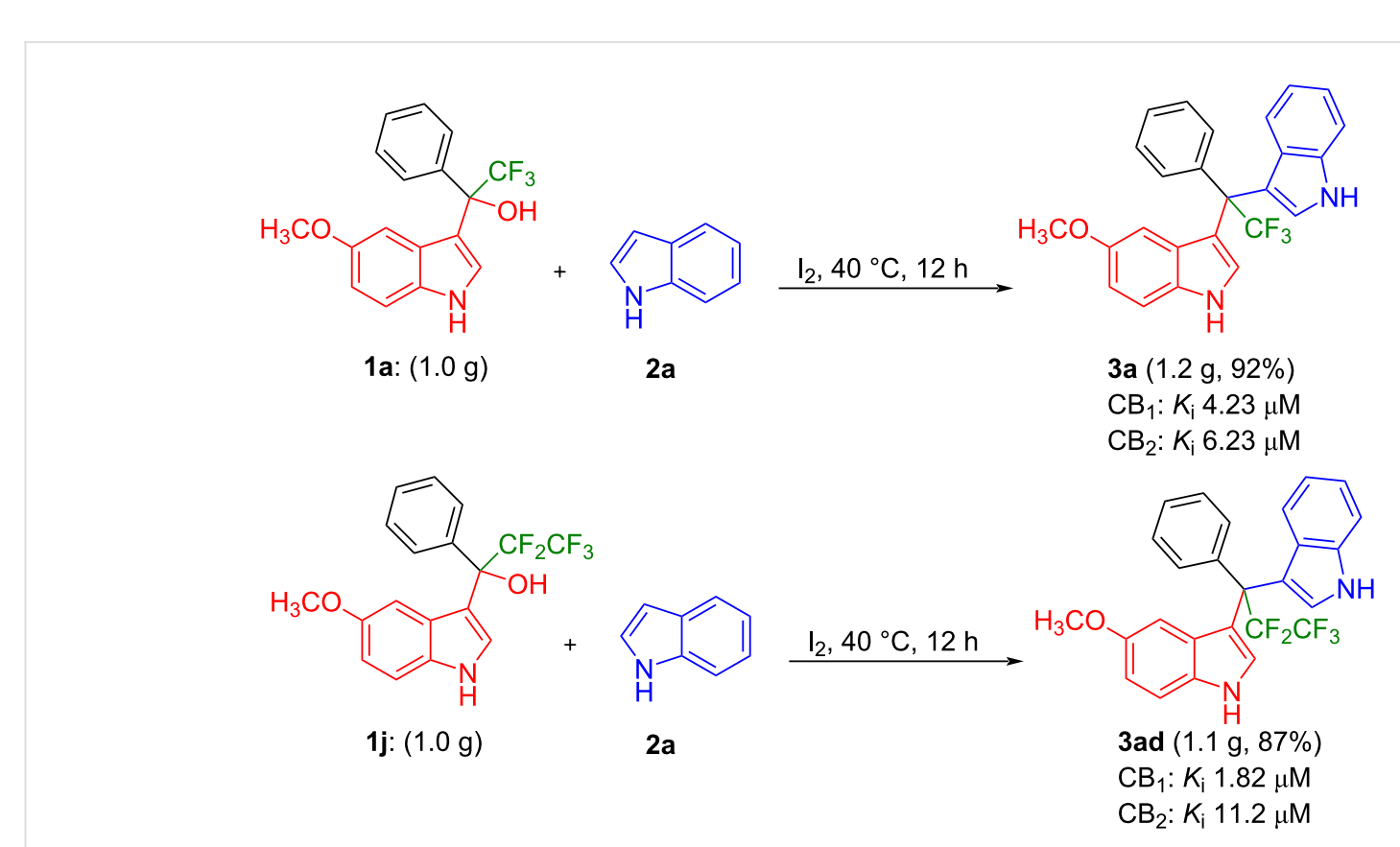

Figure 4: Gram-scale synthesis of unsymmetrical DIMs 3a and 3ad. 
Table 5: Binding affinities of unsymmetrical fluoromethyl-substituted DIM derivatives for cannabinoid receptors.

\section{Compound}

Structure
Human $\mathrm{CB}_{1}$ receptor

Human $\mathrm{CB}_{2}$ receptor

Radioligand binding assay

$\begin{array}{ll}K_{\mathrm{i}} \pm \operatorname{SEM}(\mu \mathrm{M}) & K_{\mathrm{i}} \pm \operatorname{SEM}(\mu \mathrm{S}) \\ \left(\mathrm{vs}\left[{ }^{3} \mathrm{H}\right] \mathrm{CP} 55,940\right) & \left(v s\left[{ }^{3} \mathrm{H}\right] \mathrm{CP} 55,940\right)\end{array}$

I [41]

See Figure 1 for structure

4.3

1.1<smiles>COc1ccc2[nH]cc(C(c3ccccc3)(c3ccccc3)C(F)(F)F)c2c1</smiles>

$4.23 \pm 0.03$

$6.04 \pm 0.11$

$3 a$<smiles>COc1ccc2[nH]cc(C(c3ccccc3)(c3ccccc3)c3c[nH]c4cccc(OC)c34)c2c1</smiles>

$7.64 \pm 0.80$

$4.75 \pm 0.34$

$3 b$

$3.21 \pm 0.25$

$4.47 \pm 0.12$<smiles>C=C(C(F)(F)F)C(CC)(c1c[nH]c2ccc(OC)cc12)C(F)(F)F</smiles>

$4.02 \pm 0.22$

$4.62 \pm 0.33$<smiles>COc1ccc2[nH]cc(C(c3ccccc3)(c3ccccc3)C(F)(F)F)c2c1</smiles>

$4.78 \pm 1.26$

$9.90 \pm 1.45$<smiles>CCC(C1=CNCC1)(c1c[nH]c2ccc(OC)cc12)C(F)(F)F</smiles>

$2.04 \pm 0.08$

$6.14 \pm 0.13$

$3 n$<smiles></smiles> 
Table 5: Binding affinities of unsymmetrical fluoromethyl-substituted DIM derivatives for cannabinoid receptors. (continued)

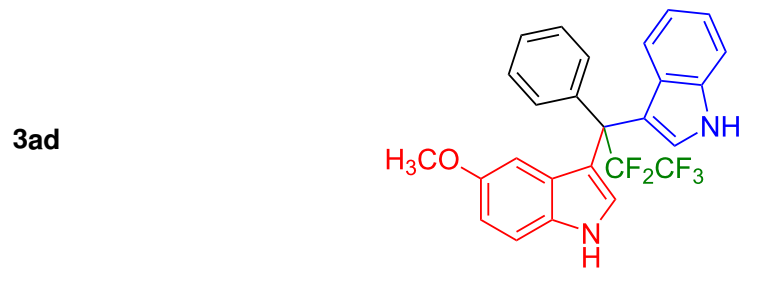

$1.82 \pm 0.09$

$11.2 \pm 0.5$

present series with a $K_{\mathrm{i}}$ value of $1.82 \mu \mathrm{M}$. The binding curves of $\mathbf{3 e}$ and 3ad are depicted in Supporting Information File 1, Figure S1.

Compound 3e showed similar binding affinities at both $\mathrm{CB}_{1}$ and $\mathrm{CB}_{2}$ receptor. Therefore, it was selected to determine and compare its functional activity at both receptor subtypes. Compound 3ad was selected due to its high $\mathrm{CB}_{2}$ receptor affinity and selectivity. It is well known that $\mathrm{CB}_{1}$ receptors exhibit high constitutive activity [41]. Compound $\mathbf{3 e}$ reduced the basal activity of $\mathrm{CB}_{1}$ receptors (Supporting Information File 1, Figure $\mathrm{S} 2 \mathrm{~A}$ ) but not that of $\mathrm{CB}_{2}$ receptors indicating that this compound acts as an inverse agonist $\left(\mathrm{EC}_{50} 0.786 \pm 0.233 \mu \mathrm{M}\right)$ at $\mathrm{CB}_{1}$ receptors (Supporting Information File 1, Figure S2B). This effect was less pronounced for 3ad. Non-transfected cells used as controls also did not show any effect after treatment with 3ad (Supporting Information File 1, Figure S2C). DIM was previously shown to be weak inverse agonist at $\mathrm{CB}_{1}$ receptors which is consistent with our current findings for DIM derivatives 3ad and especially 3e [42]. Next, we investigated the antagonistic effect of $\mathbf{3 e}$ at $\mathrm{CB}_{1}$ receptors (Supporting Information File 1, Figure $\mathrm{S} 3 \mathrm{~A})$. Compound 3e blocked $\mathrm{CB}_{1}$ receptor activation with an $\mathrm{IC}_{50}$ value of $5.68 \pm 0.54 \mu \mathrm{M}$, while it was weaker in inhibiting $\mathrm{CB}_{2}$ receptor activation. Similarly, 3ad was also able to fully block $\mathrm{CB}_{1}$ receptor activation $\left(\mathrm{IC}_{50}\right.$ value of $5.22 \pm 0.68 \mu \mathrm{M})$. Our results indicate that the new DIM derivatives act as potent $\mathrm{CB}_{1}$ receptor antagonists with inverse agonistic activity, i.e., they stabilize the inactive receptor conformation. Further optimization is warranted. This class of compounds also possesses potential for the development of $\mathrm{CB}_{2}$ selective or dual $\mathrm{CB}_{1} / \mathrm{CB}_{2}$-receptor antagonists.

Based on previous reports [25-35,43-53], a plausible reaction mechanism is proposed for the synthesis of $\mathbf{3 a}$ as an example, as<smiles>COc1ccc2[nH]cc(C(O)(c3ccccc3)C(F)(F)F)c2c1</smiles>

$1 a$

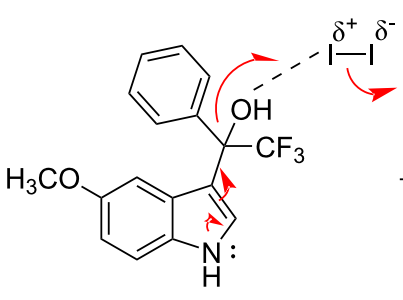

A

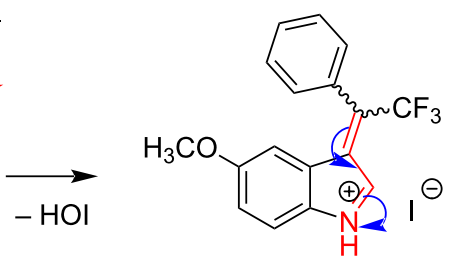

vinyliminium B

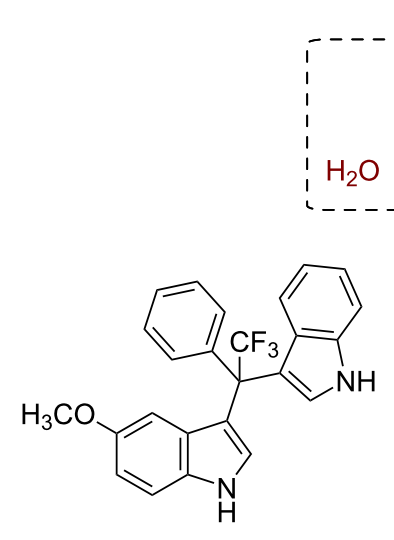

$3 a$

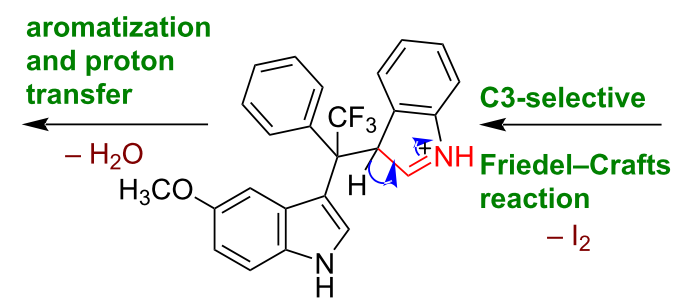

D
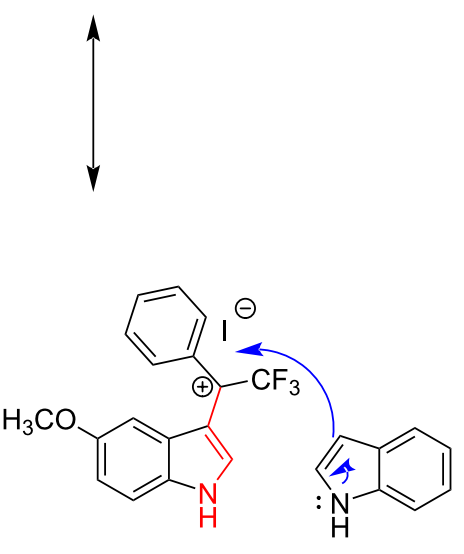

C 
depicted in Figure 5. We suggest that the reaction is initiated by iodine-mediated activation of the secondary alcohol in compound 1a (A), followed by elimination of HOI to generate the vinyliminium ion species $\mathbf{B}$ (see mesomeric structure $\mathbf{C}$ ) [52] This electrophilic intermediate undergoes a C3-selective Friedel-Crafts reaction with $\mathbf{2 a}$ to deliver intermediate $\mathbf{D}$, and the catalyst $\mathrm{I}_{2}$ is regenerated by the reaction of $\mathrm{HOI}$ and $\mathrm{I}^{-}$(see $\mathbf{C}$ to $\mathbf{D}$ in box highlighted by dashed line). The intermediate $\mathbf{D}$ is stabilized by aromatization yielding product $3 \mathbf{a}$ and $\mathrm{H}_{2} \mathrm{O}$.

\section{Conclusion}

The described novel and efficient synthetic protocol provides a convenient access to a wide range of unsymmetrical trifluoromethylated 3,3'-diindolylmethanes via $\mathrm{I}_{2}$-catalyzed Friedel-Crafts alkylation reaction of trifluoromethylated (indol3-yl)-1-phenylethan-1-ols with substituted indoles. The method was also extended to the synthesis of pentafluoroethylated and heptafluoropropylated-DIMs. It constitutes an important addition to the active field of DIM syntheses facilitating the preparation of unsymmetrical quaternary DIMs without the need for chlorinated solvents, high temperatures, or heavy-metal catalysts. A broad range of substrates is tolerated and the reaction is suitable for large-scale preparation of the target compounds. The outlined methodology allows for the rapid generation of structurally diverse DIM derivatives to study structure-activity relationships, to optimize biological activity and other properties in order to prepare tool compounds and future drugs. Several compounds displayed micromolar binding affinities toward $\mathrm{CB}_{1}$ and $\mathrm{CB}_{2}$ receptors acting primarily as $\mathrm{CB}_{1}$ receptor antagonists/inverse agonists. We are confident that our straightforward new approach will enable us and others to extensively investigate these bioactive molecules and their targets in future studies.

\section{Supporting Information}

\section{Supporting Information File 1}

Experimental and analytical data.

[https://www.beilstein-journals.org/bjoc/content/

supplementary/1860-5397-17-102-S1.pdf]

\section{Funding}

T.P. is grateful to the Alexander von Humboldt (AvH) foundation and to Bayer Pharma for a postdoctoral fellowship. ABM and CEM were supported by the Deutsche Forschungsgemeinschaft (DFG) within the Research Training Group GRK 1873 "Pharmacology of 7TM-receptors and downstream signaling pathways". A.B.M., L.L.W., and C.E.M. are grateful to the German Federal Ministry for Education and Research
(BMBF) and the Bonn International Graduate School of Drug Sciences (BIGS DrugS) for financial support. A.B.M. was supported by the Ministry of Finance of Indonesia in the scheme of Indonesia Endowment Fund for Education (Lembaga Pengelola Dana Pendidikan (LPDP).

\section{ORCID ${ }^{\circledR} \mathrm{iDs}$}

Thanigaimalai Pillaiyar - https://orcid.org/0000-0001-5575-8896 Andhika B. Mahardhika - https://orcid.org/0000-0002-0456-1353 Christa E. Müller - https://orcid.org/0000-0002-0013-6624

\section{References}

1. Garbe, T. R.; Kobayashi, M.; Shimizu, N.; Takesue, N.; Ozawa, M.; Yukawa, H. J. Nat. Prod. 2000, 63, 596-598. doi:10.1021/np990517s

2. Queiroz, M. M. F.; Queiroz, E. F.; Zeraik, M. L.; Ebrahimi, S. N.; Marcourt, L.; Cuendet, M.; Castro-Gamboa, I.; Hamburger, M.; da Silva Bolzani, V.; Wolfender, J.-L. J. Nat. Prod. 2014, 77, 650-656. doi:10.1021/np401003p

3. Pathak, T. P.; Osiak, J. G.; Vaden, R. M.; Welm, B. E.; Sigman, M. S. Tetrahedron 2012, 68, 5203-5208. doi:10.1016/j.tet.2012.03.075

4. Gong, Y.; Sohn, H.; Xue, L.; Firestone, G. L.; Bjeldanes, L. F. Cancer Res. 2006, 66, 4880-4887. doi:10.1158/0008-5472.can-05-4162

5. Sivaprasad, G.; Perumal, P. T.; Prabavathy, V. R.; Mathivanan, N. Bioorg. Med. Chem. Lett. 2006, 16, 6302-6305. doi:10.1016/j.bmcl.2006.09.019

6. Sashidhara, K. V.; Kumar, M.; Sonkar, R.; Singh, B. S.; Khanna, A. K.; Bhatia, G. J. Med. Chem. 2012, 55, 2769-2779. doi:10.1021/jm201697v

7. Sashidhara, K. V.; Modukuri, R. K.; Sonkar, R.; Rao, K. B.; Bhatia, G. Eur. J. Med. Chem. 2013, 68, 38-46. doi:10.1016/j.ejmech.2013.07.009

8. Kim, H. J.; Lee, H.; Lee, J. H.; Choi, D. H.; Jung, J. H.; Kim, J. S. Chem. Commun. 2011, 47, 10918-10920. doi:10.1039/c1cc13481g

9. He, X.; Hu, S.; Liu, K.; Guo, Y.; Xu, J.; Shao, S. Org. Lett. 2006, 8, 333-336. doi:10.1021/ol052770r

10. Imran, S.; Taha, M.; Ismail, N. Curr. Med. Chem. 2015, 22, 4412-4433. doi:10.2174/0929867322666151006093930

11. Jamsheena, V.; Shilpa, G.; Saranya, J.; Harry, N. A.; Lankalapalli, R. S.; Priya, S. Chem.-Biol. Interact. 2016, 247, 11-21. doi:10.1016/j.cbi.2016.01.017

12. Ichite, N.; Chougule, M. B.; Jackson, T.; Fulzele, S. V.; Safe, S.; Singh, M. Clin. Cancer Res. 2009, 15, 543-552. doi:10.1158/1078-0432.ccr-08-1558

13. Safe, S.; Papineni, S.; Chintharlapalli, S. Cancer Lett. 2008, 269 , 326-338. doi:10.1016/j.canlet.2008.04.021

14. Sujatha, K.; Perumal, P. T.; Muralidharan, D.; Rajendran, M. Indian J. Chem. 2009, 48B, 267-272.

15. Biersack, B. Cancer Drug Resist. 2020. doi:10.20517/cdr.2020.53

16. https://clinicaltrials.gov/ct2/show/study/NCT00888654?term=diindolylm ethane\&cond=Prostate+Cancer (accessed Oct 18, 2020).

17. Del Priore, G.; Gudipudi, D. K.; Montemarano, N.; Restivo, A. M. Malanowska-Stega, J.; Arslan, A. A. Gynecol. Oncol. 2010, 116 464-467. doi:10.1016/j.ygyno.2009.10.060

18. Kobayashi, M.; Aoki, S.; Gato, K.; Matsunami, K.; Kurosu, M.; Kitagawa, I. Chem. Pharm. Bull. 1994, 42, 2449-2451. doi:10.1248/cpb.42.2449 
19. Shiri, M.; Zolfigol, M. A.; Kruger, H. G.; Tanbakouchian, Z. Chem. Rev. 2010, 110, 2250-2293. doi:10.1021/cr900195a

20. Palmieri, A.; Petrini, M. Synthesis 2019, 829-841. doi:10.1055/s-0037-1610349

21. Pillaiyar, T.; Uzair, M.; Ullah, S.; Schnakenburg, G.; Müller, C. E. Adv. Synth. Catal. 2019, 361, 4286-4293. doi:10.1002/adsc.201900688

22. Purser, S.; Moore, P. R.; Swallow, S.; Gouverneur, V. Chem. Soc. Rev. 2008, 37, 320-330. doi:10.1039/b610213c

23. Isanbor, C.; O’Hagan, D. J. Fluorine Chem. 2006, 127, 303-319. doi:10.1016/j.jfluchem.2006.01.011

24. Prakash, G. K. S.; Wang, F. Chim. Oggi 2012, 30, 30-36.

25. Sarver, P. J.; Bacauanu, V.; Schultz, D. M.; DiRocco, D. A.; Lam, Y.-h.; Sherer, E. C.; MacMillan, D. W. C. Nat. Chem. 2020, 12, 459-467. doi:10.1038/s41557-020-0436-1

26. He, Y.-Y.; Sun, X.-X.; Li, G.-H.; Mei, G.-J.; Shi, F. J. Org. Chem. 2017, 82, 2462-2471. doi:10.1021/acs.joc.6b02850

27. Inamdar, S. M.; Gonnade, R. G.; Patil, N. T. Org. Biomol. Chem. 2017, 15, 863-869. doi:10.1039/c6ob02595a

28. Suárez, A.; Martínez, F.; Sanz, R. Org. Biomol. Chem. 2016, 14, 11212-11219. doi:10.1039/c6ob02125e

29. Zeng, X.-F.; Ji, S.-J.; Wang, S.-Y. Tetrahedron 2005, 61, 10235-10241. doi:10.1016/j.tet.2005.08.040

30. Pillaiyar, T.; Gorska, E.; Schnakenburg, G.; Müller, C. E. J. Org. Chem. 2018, 83, 9902-9913. doi:10.1021/acs.joc.8b01349

31. Deb, M. L.; Das, C.; Deka, B.; Saikia, P. J.; Baruah, P. K. Synlett 2016, 2788-2794. doi:10.1055/s-0036-1588887

32. Jadhav, S. D.; Singh, A. J. Org. Chem. 2016, 81, 522-531. doi:10.1021/acs.joc.5b02383

33. Lancianesi, S.; Palmieri, A.; Petrini, M. Adv. Synth. Catal. 2012, 354, 3539-3544. doi:10.1002/adsc.201200632

34.Sun, F.-L.; Zheng, X.-J.; Gu, Q.; He, Q.-L.; You, S.-L. Eur. J. Org. Chem. 2010, 47-50. doi:10.1002/ejoc.200901164

35. Pillaiyar, T.; Sedaghati, M.; Schnakenburg, G. Beilstein J. Org. Chem. 2020, 16, 778-790. doi:10.3762/bjoc.16.71

36. Sasaki, S.; Ikekame, Y.; Tanayama, M.; Yamauchi, T.; Higashiyama, K. Synlett 2012, 2699-2703. doi:10.1055/s-0032-1317485

37. Ling, Y.; An, D.; Zhou, Y.; Rao, W. Org. Lett. 2019, 21, 3396-3401. doi:10.1021/acs.orglett.9b01135

38. Pillaiyar, T.; Köse, M.; Sylvester, K.; Weighardt, H.; Thimm, D.; Borges, G.; Förster, I.; von Kügelgen, I.; Müller, C. E. J. Med. Chem. 2017, 60, 3636-3655. doi:10.1021/acs.jmedchem.6b01593

39. Xiao, J.; Wen, H.; Wang, L.; Xu, L.; Hao, Z.; Shao, C.-L.; Wang, C.-Y. Green Chem. 2016, 18, 1032-1037. doi:10.1039/c5gc01838b

40. Wen, H.; Wang, L.; Xu, L.; Hao, Z.; Shao, C.-L.; Wang, C.-Y.; Xiao, J. Adv. Synth. Catal. 2015, 357, 4023-4030. doi:10.1002/adsc.201500500

41. Felder, C. C.; Joyce, K. E.; Briley, E. M.; Mansouri, J.; Mackie, K.; Blond, O.; Lai, Y.; Ma, A. L.; Mitchell, R. L. Mol. Pharmacol. 1995, 48, 443-450.

42. Yin, H.; Chu, A.; Li, W.; Wang, B.; Shelton, F.; Otero, F.; Nguyen, D. G.; Caldwell, J. S.; Chen, Y. A. J. Biol. Chem. 2009, 284, 12328-12338. doi:10.1074/jbc.m806516200

43. Mei, G.-J.; Shi, F. J. Org. Chem. 2017, 82, 7695-7707. doi:10.1021/acs.joc.7b01458

44. Wang, L.; Chen, Y.; Xiao, J. Asian J. Org. Chem. 2014, 3, 1036-1052. doi:10.1002/ajoc.201402093

45. Li, X.; Tan, W.; Gong, Y.-X.; Shi, F. J. Org. Chem. 2015, 80 , 1841-1848. doi:10.1021/j0502782b
46. Tan, W.; Du, B.-X.; Li, X.; Zhu, X.; Shi, F.; Tu, S.-J. J. Org. Chem. 2014, 79, 4635-4643. doi:10.1021/j0500644v

47. Liu, Y.; Zhang, H.-H.; Zhang, Y.-C.; Jiang, Y.; Shi, F.; Tu, S.-J. Chem. Commun. 2014, 50, 12054-12057. doi:10.1039/c4cc02056a

48. Lu, Y.-N.; Ma, C.; Lan, J.-P.; Zhu, C.; Mao, Y.-J.; Mei, G.-J.; Zhang, S.; Shi, F. Org. Chem. Front. 2018, 5, 2657-2667. doi:10.1039/c8qo00565f

49. Sun, X.-X.; Zhang, H.-H.; Li, G.-H.; He, Y.-Y.; Shi, F. Chem. - Eur. J. 2016, 22, 17526-17532. doi:10.1002/chem.201603049

50. Zhou, L.-J.; Zhang, Y.-C.; Zhao, J.-J.; Shi, F.; Tu, S.-J. J. Org. Chem. 2014, 79, 10390-10398. doi:10.1021/j0501989x

51. Liu, H.; Zheng, C.; You, S.-L. J. Org. Chem. 2014, 79, 1047-1054. doi:10.1021/j0402511b

52. Čebular, K.; Stavber, S. Pure Appl. Chem. 2018, 90, 377-386. doi:10.1515/pac-2017-0414

53. Breugst, M.; von der Heiden, D. Chem. - Eur. J. 2018, 24, 9187-9199. doi:10.1002/chem.201706136

\section{License and Terms}

This is an Open Access article under the terms of the Creative Commons Attribution License (https://creativecommons.org/licenses/by/4.0). Please note that the reuse, redistribution and reproduction in particular requires that the author(s) and source are credited and that individual graphics may be subject to special legal provisions.

The license is subject to the Beilstein Journal of Organic Chemistry terms and conditions: (https://www.beilstein-journals.org/bjoc/terms)

The definitive version of this article is the electronic one which can be found at: https://doi.org/10.3762/bjoc. 17.102 